\title{
On Truth ANd Opacity. Symbolic Translation AND LegibiLIty in Contemporary Text-Based Cuban Art
}

\author{
Sobre verdad y opacidad. Traducción simbólica y legibilidad en el arte \\ textual cubano contemporáneo
}

\author{
CARlos Garrido CASTELLANo \\ Centro de Estudos Comparatistas. Universidade de Lisboa \\ cgc@campus.ul.pt
}

\begin{abstract}
: this paper examines text-based artworks that employ symbolic translations as a way of analyzing the discursive constrains regulating the Cuban public sphere. Through a revision of artistic projects that turn to translation and intend to provoke the spectator's active engagement, I seek to understand which possibilities are opened by translation in order to escape the burdens of representation and commoditization shaping contemporary Cuban art. I argue that the encouragement of direct experience could be framed as that possible alternative. The potential attributed to experience and practicality, nevertheless, cannot be directly deduced from the artist's intentions, being contingent ultimately of how each project works.
\end{abstract}

Keywords: Caribbean, Conceptualism, Contemporary Art, Cuba, Curatorial Politics, Visual Translation

Resumen: este texto analiza proyectos artísticos basados en contenido textual que recurren a la traducción simbólicamente para examinar las limitaciones discursivas que determinan la esfera pública cubana contemporánea. A través de una revisión de discursos artísticos que se basan de la traducción para provocar una implicación activa por parte de los espectadores, pretendo entender qué posibilidades se abren a través de la traducción a la hora de escapar a las limitaciones de la representación y la mercantilización. Defiendo que el fomento de una experiencia directa puede ser esa alternativa. El potencial atribuido a la experiencia y a lo práctico, sin embargo, no podrá deducirse inmediatamente de las intenciones de los artistas, resultando contingente en todo caso en cada proyecto artístico.

Palabras clave: Caribe, conceptualismo, arte contemporáneo, Cuba, políticas curatoriales, traducción visual 


\section{Introduction ${ }^{1}$}

For language, including visual language, can be deployed not only as a means of communication, but also as an instrument for strategically planned discommunication or even self-induced ex-communication, in other words, for deliberately abstaining for the communicating community. Boris Groys, "Back from the Future"

La realidad absoluta was Luis Gómez's contribution to the Eighth edition of the Havana Biennial in 2003. It presented a plastic, translucent, polygonal tent which the public was invited to enter. Behind the fabric the audience could glimpse several human silhouettes lit up by reading lamps. Each lamp illuminated a lecturer standing for a religion and a cultural community. The role of the seven lecturers was clear: they should read each one, in their original language, the sacred text of the culture they "belong to". Immersed in that scenario and deprived of sight, visitors could approach the "essence" of divine truth in its original version, in the most direct possible way. However, at the same time, their perception of that truth was foreclosed by the fact that the seven lectures came to them at the same time, generating a Babel-like confusion, as a murmur that Gómez aimed to make equivalent to absolute reality.

Ultimately, as we will see, the denial of perception and communication present in La realidad absoluta, which aims to provoke spectators' self-awareness through the negative experience they face, is indissolubly linked to translation and language. It is that negativity which confers the artwork its main aesthetic values. One could say that the project deals with the distance between ideal and practical acts of communication and with the separation between written language and performative acts of speech, pointing out how everyday acts are dissolved from an unattainable upper dimension of perfection. In that sense, one could think that the installation's main objective is to render the public aware of the difficulties associated with intercultural communication and translation, as well as to point out the distance between any enunciation with pretensions of truth and its critical materialization.

This interpretation bears key implications for our ends in this text. Herein I will analyze how contemporary Cuban text-based art has used translation in symbolic ways in order to examine critically the shifting predicament of Cuban sociopolitical reality and the incardination of Cuban

\footnotetext{
${ }^{1}$ Acknowledgements: The research for this article arises from several fieldwork stays in Cuba and the United States. It was funded by a FCT Post-Doctoral Scholarship, being part of the project "Artistic Curatorship and Difference in the Postcolonial Lusophone and Hispanophone Atlantic Contexts" (SFRH/BDP/92492/2013). Special thanks to the Wilfredo Lam Center in Havana, the Bobst Library of New York University and the Lilly Library in Duke University.
} 
artistic within a transnational sphere. ${ }^{2}$ Under that view, I assert that Cuban artistic practice has been dominated by the restrictive communicational framework set up by state power and the expectations arising from the incorporation of Cuban artistic practice into the rhythms of art market. Whereas the critical self-reflexiveness pursued by contemporary Cuban artists has received wide attention (Tonel, 2006; Fusco, 2001; Borràs and Zaya, 1996; Santana, 2007), as has the use of strategies such as irony and humor in the elaboration of a discourse aware of the artist's position (Weiss, 2011) the relation between translation and speech has received much less attention, despite the relevance of text-based artistic production in the configuration of Cuban contemporary artistic practice (Camnitzer, 2003).

That relation reveals to be especially eloquent concerning the reframing of art audiences in the Cuban context. Within the last decades, many initiatives —art exhibitions, artistic interventions, open symposia, artist-managed spaces, not to mention the Havana Biennial, which from the 2000s on has taken place increasingly within the public space of the city - have privileged the active implication of the audiences. At the same time, those initiatives have sought to expand the influence of artistic practice outside the small group of contemporary art connoisseurs, intending to engage with broader publics. The artistic projects I analyze here form part of that logic. Those projects are, thus, demanding a new subjectivity in the form of a more implicated audience, yet, as we will see, this will not always be achieved in the same ways and to the same degree. By examining artworks using translation heterogeneously, my main objective will be to assess the role of translation in visual arts. The point, then, will be to discern whether symbolic translation stands as a powerful tool when used by Cuban visual artists in order to subvert the restrictions imposed by the Cuban communicational framework and the expectations of Mainstream economic fluxes; or, on the contrary, if it has been used solely in order to generate a sense of "criticality", an idea of artistic independence and critical awareness. In that sense, I sustain that translation has played a central role in ensuring a degree of experimentation and "practicality" that will serve artists to reveal the limitations of art, understood as a privileged communicational sphere within Cuban reality since the eighties. By then, art critic and curator Gerardo Mosquera introduced the idea of a "substitutive space" referring to contemporary Cuban art. According to Mosquera, contemporary art allowed for a more intense critique in comparison to literature, and because of that it substituted the political realm as the main terrain for social demands and new articulations of political criticism. Being politics a forbidden territory, art provided a useful way to address political issues

\footnotetext{
${ }^{2}$ My use of symbolic translation thorough this text intends to allude at how visual artist have addressed the predicament of Cuban transnational public sphere by analyzing the distance between different linguistic instances, among them the official rhetoric and everyday language, and capitalist exchanges and Cuban sociopolitical reality.
} 
due to its non-representational, non-narrative character. Moreover, Mosquera argues, artistic practice will soon become a lingua franca that allowed Cuban artists to engage, even in a position of preponderance, in the debates on globalization and national politics (Mosquera, 2009, 2010).

While recognizing, with Mosquera, that visual arts played a central role within the definition of a Cuban public sphere, I sustain here that textbased artworks using translation operate in radically different terms. The artistic projects I analyze here can be confronted at two different levels. The first one consists on emptying the content of symbolically and ideologically charged references. This strategy could be framed as being close to appropriation and referential, ironic, visual quotation widely present within Cuban art criticism. Important as this option is in revealing the ways in which cultural exchanges are permeated by political power and subjected to the revolutionary intelligentsia, I will argue throughout this paper that it reveals itself incomplete or unfertile. It depends too much on the "clairvoyance" of the artist, the only person who is able to "awaken" an ignorant audience and to alert it about how power operates in each hermeneutical or communicational act. Instead of relying on the "criticality" of text-based projects (Llanes, 2010), a second interpretation, I argue, arises as much more fruitful, one based on an appraisal of practice and experience. Under that view, translation offers Cuban artists the possibility of experimenting, detaching thus the creative process from the consecution of a final, marketable product. This will lead to use translation as a useful tool to engage with "subtle uses of power through controls of communication" (Fabian, 1991: 3). Of course, this strategy does not put the artists using it outside the Cuban art world and outside the burdens of criticism and "criticality" and, as we will see, several difficulties will arise from that viewpoint. However, that second, experience-based possibility, I sustain, can open up an interesting framework for aesthetic creativity in Cuba within the last decades, while revealing the pitfalls of gratuitously appreciative understandings of the potential of art.

\section{Experience and Practice beyond Criticality}

La realidad absoluta provides a good example of the possibilities and the limitations of both understandings. Let us consider first the project as a collapse of communication. From that viewpoint, the installation arises as an ambiguous project open to many possible interpretations. By gathering the audience within the space of the tent and immersing it in the murmuring chaos of voices, it deals with the common, with the conditions regulating the configuration of collective subjectivities around an external, "superior" entity or agenda. At the same time, La realidad absoluta is about the contingency of communication and the refusal of domesticating difference within discursive, intercultural interaction. The installation bears, without addressing them directly, several connotations concerning the predicament of Cuban public sphere: the distance between official 
rhetoric and reality; that is, the dissociation between the "absolute reality" of revolutionary ideals and its factical materialization. Gómez's installation, thus, appears ambiguously refractory of univocal representation and interpretations, forcing us to rely on the (imperfect) experience we get when immersed in the chaos of divine voices to draw any conclusion.

The artist's role in that case would be to collapse the communicative process in order to make by that way the spectator aware of how ideologically-bounded the interpretative and communicative universes are. In Gómez's installation, the impurity, and ultimately the impossibility of translation leads us to perceive the non-existence of absolute reality, that is, how any approach to the nucleus of reality appears as contingent and doomed to failure. Under this light, then, the installation operates apparently as a powerful critical tool, one which used in the right way and by the right person, would correct and improve the ideological apparatus under which Cuban cultural production operates. After leaving Gómez's tent, the spectator would have perceived how "contaminated" by external forces his/her "relational" engagement with the "absolute reality" of language is, and consequently would adopt a critical position of alert (Bourriaud, 2002). In that sense, even when the content of the installation drives the spectator towards a privative experience, to a negation of meaning, ultimately it would bear a transformative potential that would destabilize the symbolic order the artwork intends to undermine. ${ }^{3}$

This approach appears to be especially in tune with Rancière's frequently quoted idea of the distribution of the sensible (2004). The disruptive effect operated by La realidad absoluta would have the effect of transforming the parameters of the sayable and the thinkable within Cuban reality, by operating within "the aesthetic regime". However, if we consider the special predicament of Cuban public sphere, this interpretation will reveal itself problematic, giving way to multiple questions: How emancipative are a set of "critical" creative practices accepted and even encouraged by the revolutionary regime and embraced and fostered by art institutions and art criticism? Are we to understand La realidad absoluta as a direct attack against the limiting forces of revolutionary censorship? To what extent does the installation operate the "emancipative" potential it carries? A quick look at La realidad absoluta will reveal the limitations of that view. We could understand Gómez's

${ }^{3}$ It is striking how the celebration of some projects has been based on that will of destabilizing the Cuban communicational spheres, regardless of artistic projects' practical functioning. Tania Bruguera's version of Los susurros the Tatlin displayed in 2009 as part of the Havana Biennial provides a clear example of that. In this case, Bruguera disposed a podium in which one minute of "non censored speech" was granted to any person interested in using this prerogative. After that minute, two military-dressed performers put a pigeon on the speaking person's shoulder, emulating the inaugural moment of the Revolution in which a pigeon was told to get down and to pose itself on Castro's shoulder. Bruguera's performance had a vast repercussion within the media and both national and international critical debates; however, as La realidad absoluta shows, its ambitions and objectives were already present in other less spectacular Cuban visual art projects, which ultimately function in a similar way. 
installation just as an exercise of "negative" translation, from which would be derived an emancipative attitude by part of the audience. But then, we would be overestimating artistic agency, by conceiving its functioning as independent from an equally politicized and "polluted" cultural sphere. It is time, then, to explore the second interpretation I introduced above.

It is important to note that all the possible interpretations of $L a$ realidad absoluta above outlined are indissolubly linked to experience. Any indirect approach to the documentation generated by the project reveals itself to be incomplete. Even the video documenting the action, which shows a chaotic multitude wandering inside the tent, fails to capture the essence of the project. Instead, the project only achieves its function when we are inside the tent, immersed in the linguistic chaos that Gómez identifies with absolute reality. The spectator is committed to developing a hermeneutical role, trying to obtain a common understanding out of the overlapping of voices and experiences and to overcoming the discursive resistance permeating its perception. However, this experience will reveal itself futile only by the saturation of language and content. Experience, then, operates a decisive role, but it does so in a negative way: the unattainable condition of absolute reality, of absolute truth, is equated to a denial of participation and engagement. ${ }^{4}$

Yet, at the same time, La realidad absoluta challenges the agency of the public, of the performers-readers, and of the artist himself. The installation complex does not conceive its audience as a group of passive subjects waiting to be "illustrated" and "awakened" by the critical clairvoyance of the artist. After a moment of astonishment and contemplation, the public who visited the installation in the Havana Biennial started talking, confounding thus their voices with the sonic performance, and therefore adding another layer to the chaotic configuration displayed by Gómez. The use of the tent as a space for interaction and reflection partially independent of the artist's intention revealed to be fundamental, since it triggered a more participative behavior from the audience. By so doing, the public could in some ways appropriate the artwork, polluting the "noise" of divine truth, and therefore the authorial, position of the artist and of the art institution, simultaneously compromising the "criticality" of the installation through the incorporation of non-expected speech. Translation arises, then, not as a project condemned to failure, but as a nuanced framework in which experimentation and practice can take place.

\section{Reframing the Sayable}

In the context of Cuban art, the sayable and the visible reveal themselves not as a complete modification of the terms determining the political and the common, but as a nuanced set of maneuvers defying, channeling and

\footnotetext{
${ }^{4}$ This distance is not new at all. On the contrary, it centers to a great extent contemporary artistic practice. A critical view on the "aesthetics of disengagement" in Kester, 2011.
} 
appropriating at the same time, the "official" revolutionary symbolic order. If, according to Rancière, "Politics, before all else, is an intervention in the visible and the sayable" (2010: 37), this only becomes true in the Cuban case after an exercise in which meaning is defied within the limits that the permanence of forms allow. Rancière's words acquire another light when confronted with what would be the motto, and the primary boundary, of Cuban cultural production, the one defined in the discourse that later on will be known as Palabras de los Intelectuales: "dentro de la revolución, todo; fuera de la revolución, nada". On one hand, this motto supposed for decades a burden that limited the activity of writers, artists and other cultural producers, and ultimately led some of them to exile, social isolation, imprisonment or even suicide. On the other, it enabled a broad margin in which "all" was allowed as long as it was inside the revolutionary order, that is, as long as it would not surpass a certain threshold of permissibility. How and for whom that threshold is defined is another question. In other words, the acceptance of any kind of criticism would not only be rejected, but it would also be embraced as a positive element fueling revolutionary energy. Consequently, under this predicament, any judgment of artistic practice as a challenge against the national political system will be missing the circumstances under which that challenge arises and how it operates. The point will not be, thus, how intense or wasted the artistic message is, how subtle or sharp the criticism, or how near or close cultural agents and creators to the image of the "organic intellectual" that Che Guevara depicted already in 1965. To measure Cuban cultural productions by the extent in which they oppose an "official culture" and define an "anti-institutional" framework without fleeing the cultural institutions highly controlled by Cuban government, ${ }^{5}$ irrevocably condemns those cultural productions to an univocal understanding, rendering them ultimately to a false oppositional dichotomy.

That dichotomy between anti-institutional and "institutionalized" art has been frequently used to measure the distance between two different "generations" of artists and two understandings of Cuban art. In that sense, whereas the eighties saw a different groups of creators supposedly defying the art institution and ultimately the whole Cuban cultural system, the Cuban art of the nineties became internationalized and commoditized. Weiss puts it very clearly when saying that - "art was again art, safely contained in institutional space" (Weiss, 2011: 187)—. More radically, Camnitzer traces a dark landscape at the beginning of the last decade of the twentieth century: ${ }^{6}$

\footnotetext{
${ }^{5}$ The Havana biennial stands for a perfect example of a cultural project whose radicalism has increasingly decreased at the same time as it has embraced and channeled "alternative" and "participative" means, including the existing museum and gallery space, engaging with "local communities" or proposing parallel communicational frameworks.

${ }^{6}$ It is symptomatic that the 2003 edition of Camnitzer's ambitious survey of Cuban art of the eighties maintained the appreciative tone of the first edition of 1994.
} 
Local primary information was inevitably masked by the imports, and artistic products started to become echoes, postponing culture instead of generating it. Art on the periphery under these conditions became more a postcultural than a cultural phenomenon. It is primarily the product of an adopted or an imposed culture rather than a contributor to a culture in action. (Camnitzer, 2003: 300)

If we approach this debate here is not to contrast different understandings and chronologies of contemporary Cuban art. What is interesting here is how the critical capacity of Cuban artworks has been measured according to their ability to escape from "containment within institutional space". Text-based artworks have not been an exception. One question arises immediately: was not the "experimental" art scene of the eighties also -and voluntarily - operating within institutional space? ${ }^{7}$ What do we expect from art? Those interpretations understand artists as being privileged translators operating in the shifting landscape in which Cuban cultural exchanges take place, as if a more "critical" artwork would be the antidote to a tradition of packaging culture and responding to foreign expectations. The problem with that position is that it presupposes the existence of a discursive "outside" of institutionalization and the market, being the responsibility of the artist to adopt a self-aware and critical attitude, and expecting that a similar reaction will follow on the side of the spectators after that. What can be done, then?

\section{Capturing Sketches}

In 1996, Antonio Eligio Fernández "Tonel", perhaps the Cuban artist who has reflected more in depth about the practice of his fellow colleagues, wrote that a great part of Cuban artistic practice had the condition of a sketch, of a school-like exercise. This would confer creativity a degree of freshness deriving from the proximity to the atmosphere of the university and the educational center from where many of them operated in the eighties. In some ways, Tonel's idea of conceiving part of the artistic production as an experimental act of sketching, of practicing, will be particularly relevant in the field of text-based art. What is interesting from this conceptualization is the way it breaks with the passivity of discoursebased productivity: Tonel's sketches do not "represent" final artworks, nor do they aspire to conceal an emancipative symbolic meaning beneath the surface of the paper. They are just practice, repetition, private jokes and references, aimed to be understood only by a limited circle of people.

\footnotetext{
${ }^{7}$ The existence of an "outside" of institutional space is centering present day debates on institutional critique and institutional exodus. If the art institution is expanding, reaching places and situations traditionally alien to artistic practice, at the same time that it integrates the criticism made by artists, curators, spectators,... within its own presentation, how are we to conceive that "outside" position? Then, whereas for some that possibility of remaining at the margin of institutionalism is no longer possible (Fraser, 2005), for others creativity and criticism still bear an "instituent" potential (Raunig and Ray, 2009).
} 
Whereas this fact somehow limits the "utopian" potential of the artwork and its aspirations of perfecting the social domain in which it is inserted, at the same time that experimental condition detaches art from a categorical affirmation or rejection of communication.

The implications of this kind of practice, which cannot be limited to the specific context of the eighties, have somehow remained present within Cuban text-based art using translation symbolically. However, it appears to be burdened by several limitations downplaying its efficacy. Consider, for instance, Jorge Wellesley's experiments with conceptualism. As Gómez, Wellesley, who emerged in the first decade of the twentieth century, is interested in analyzing how the "conditions of possibility" of any truth being strongly related to its enunciation. This is especially evident in Wellesley's work. All his projects are subsumed under the common name of "TRUTH" plus a number. By trying to explain that, Wellesley alludes to indexical reasons, but also to the problematic predicament that English language symbolizes in Cuba:

I created a sort of system that includes a chronology of the artworks I have been doing. I make a list of works in which all have the word TRUTH, and a numeration that, in a great irony, classifies and accounts the truths of the artists. I put it in English because it is something that simply accentuates the irony. Truth in English is even truer $[\ldots]^{8}$

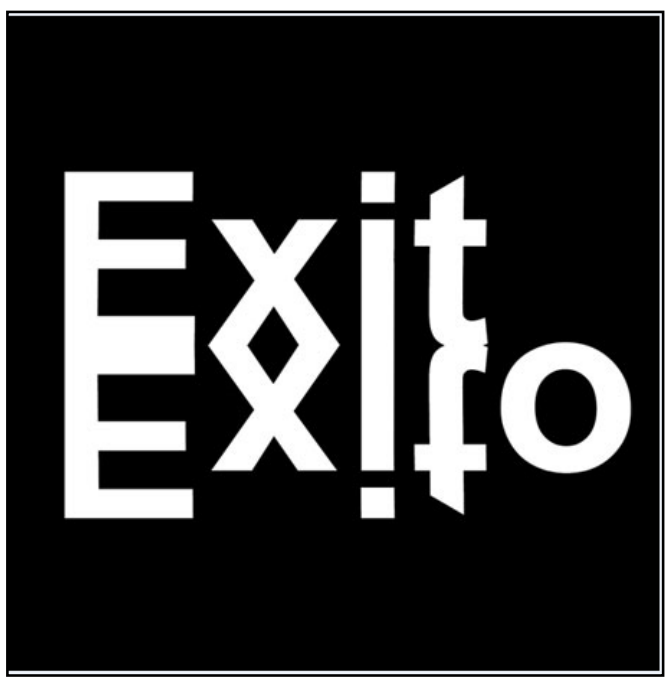

Figure 1

There is, then, a critical, ironic tone in Wellesley's work, one that is used to deconstruct the power relations determining Cuban social reality. This is evident in some of his "truths": TRUTH 0023 (Figure 1), for example, dealt with the link between reality and language, and was composed of a series

\footnotetext{
${ }^{8}$ Personal interview with the artist. Havana, 2012.
} 
of acrylic canvases in which two words ("verdad" and "mentira"; "exit" and "éxito") overlapped.

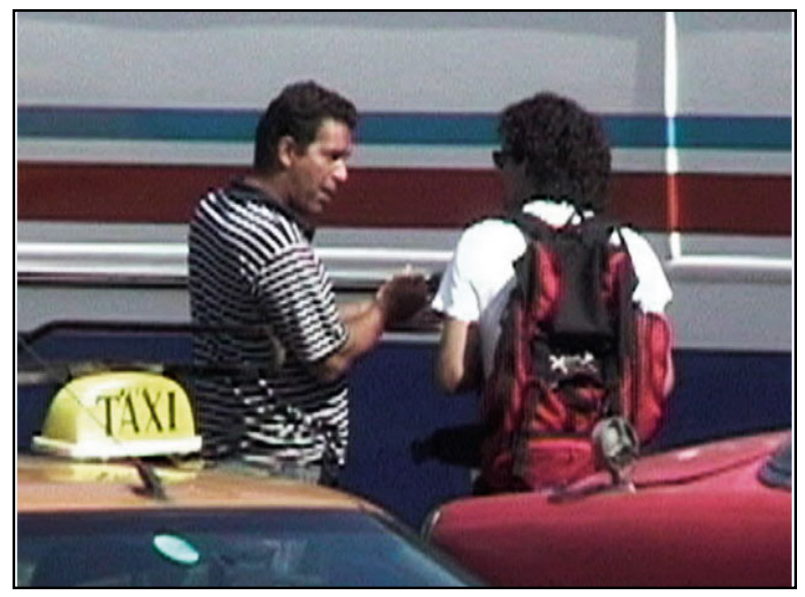

Figure 2

"Truth 0014: Profeta en su tierra" (Figure 2), on its part, implied the recording of Wellesley drifting around the streets of Havana simulating he was a tourist. During this time, the artist lived as a tourist, communicating in English and asking for basic information. The performance, developed during the exhibition time of the Havana Biennial, had the collaboration of some students in the documentation, and was conceived as an open project seeking to address multiple audiences. Translation operates in Wellesley's work as an excess, as an overload of meaning that confers each message an ironic tone. That tone, along with Wellesley's depurate and minimalist facture, close to design, distances him from Tonel's rough sketches and would render his production an evident case of "criticality". What renders Wellesley's experiments with translation interesting is that each "Truth" is materialized as a practical intervention, an exercise, dealing with a specific materialization of those power relations. Wellesley teaches at the Cuban Instituto Superior de Arte (ISA), the country's leading educational institution for fine arts, and commonly transforms his artistic production into class material.

Wellesley's interest in using English responds to a long tradition of addressing ironically Cuban artists' competence to deal with economic issues. In the nineties it became common to find titles of artworks and exhibitions of Cuban art in English, even inside the island. This presence talked about the importance of market in the Cuban artistic scene, while it was confirming that any internal dynamic would have to live with the constant gaze from the outside. Furthermore, in some cases the use of English was related to the diasporic condition adopted by many artists. In that sense, for instance, Consuelo Castañeda, part of the Eighties Generation and exiled in 1991, will hold an exhibition under the significant title of "To Be Bilingual". It was a series of painting-lessons that alluded to what would eventually become a frequent condition for many artists of the country who were forced to migrate at the beginning of the so called 
"Periodo Especial en Tiempos de Paz" [Special Period in Peace Times]. That moment showed how translation was a candent issue within Cuban civil society. The consequences of the political isolation of the island will derivate in several restrictions concerning the circulation of information and the production and display of culture, modifying the ways in which innovation and circulation operate. The dissemination of any external resource will be for a long time associated to personal experiences: individual travels and international fellowships will provide an opportunity to import books and art journals that circulate among colleagues; the existence of photographs will ease the impossibility of knowing the collections of major art museums.

The conditions which originate that tradition, however, were largely altered when Wellesley started working, and that fact diminishes substantially the potential of his experiments with English. Ultimately, Wellesley's work evidences the limitations of visual translation based on appropriation and opacity (Figure 3, "Tribute to Emptiness").

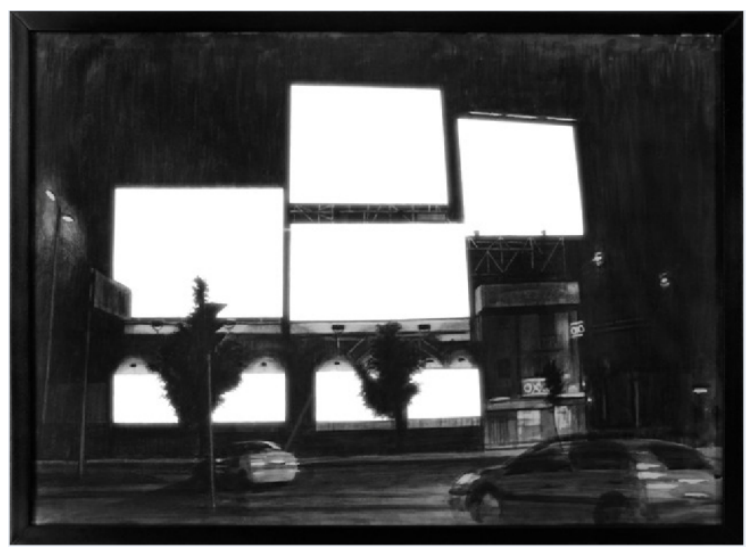

Figure 3

As in Gómez's La realidad absoluta, his "truths" are employed as a curtain that confuses and destabilizes the viewer's perception. They are no longer Tonel's sketches, operating ultimately through a very local, and localized, context. They no longer work as private jokes; rather, Wellesley's truths point to a more universal content, losing in many cases the frescura of previous experiments. The ambivalence of the Truth series is thus resolved, equated to conscious opacity, and only the conjugation of Wellesley's linguistic interests and his pedagogical activity remind in some way the practical option sketched by Tonel.

\section{Conclusions: Experience and Non-Translation}

In 2007, four years after La realidad absoluta, Luis Gómez produced a video under the title of Traducción. The video is a textual projection of a personal translation of the poetry of George and Ira Gershwin's They Can't Take that Away from Me. Against a dark backdrop, Gómez presents a written version in Spanish of the song popularized by Fred Astaire. What singularizes 
Gómez's translation is not any particular translational mistake, but the way some words repeat themselves, concatenated by a logic which implies that the artist interprets the song. So, for instance, the word "No" remains longer in the screen, and "poder" and "quitar", which are a direct translation of the song's chorus, are always framed together and decontextualized. As La realidad absoluta, Traducción is opened to two possible interpretations. The first one has to do with the video's referential character, its meaning. This would be equivalent to the confusion of the performers/readers in La realidad absoluta. What can be deduced from that view is a sense of ambivalence and ambiguity that allows the artist to deconstruct a message, thus conferring it political and cultural connotations. In this case, those are related to the ambivalence of criticism and its self-reclusion to a nostalgic, delusional position towards its object. In Shall We Dance, the movie where Gershwin's song was featured for the first time, Astaire addresses his lover Linda Keene, performed by Ginger Rogers. Knowing that Rogers is about to leave, Astaire enumerates the things he will miss from her, pointing out repeatedly "no, no, they can't take that away from me." As in Astaire's film, translation points again to an impossibility, to something that is already lost or that has always been unattainable. The visual presence of the "negative" elements of the lyric ("no" and "quitar") points in that direction. Seen from that perspective, Traducción is not far from La realidad absoluta, despite the disparity of their creative media, and consequently the role conferred to the spectatorship remains more or less the same. As in the installation that opened this article, another possibility arises if we pay attention to the ways in which Gómez reconstructed the song's lyrics. In this case the alternative potential of the video is biased, but at the same time made possible, by the ambiguity of the message and the negative reiteration of the "non-translation" undertaken by Gómez.

How seriously, then, shall we consider the intentions of those artworks? Are they "telling" something through their symbolic use of translation, or are them just illegible or without content, a demonstration of the vacuum dominating great part of present day Cuban cultural politics? The limited framework of possibility in which Traducción operates is symptomatic of the limitations present in Cuban text-based art. We have seen how many artworks intend to distance themselves from a sense of "criticality", from a referential relation with an external sphere. The interests of many Cuban artists working with translation will revolve, then, around the use of translation in order to incorporate the freshness of practice, of speech, into the rigid oppositional debates on discourse and its role in the definition of a Cuban public sphere. However, this task will not be easily achievable. Cuban text-based artwork will be subjected to many of the frequent constraints adjudicated to conceptual art: a first one has to do with the excessive dependence on discourse of the analyzed artworks. Even though they leave a possibility open for experimentation and nondetermined interaction, the artworks are too dependent on the expected 
"emancipative" results each project will have on its spectatorship. A profound gap exists between the "elements to be translated" — whether they are conceptualized as the art market, external influence, the official rhetoric - and the symbolic act of playing with them through artistic means. In that sense, the fact that we cannot find relevant experiences of "real" translation of texts and references within the Cuban artistic sphere is symptomatic.

Another limitation comes by hand of agency. Even in La realidad absoluta, an installation conceived in order to confer spectators an active role, the traditional distribution of agencies, in which the artist "controls" how the audience that will participate, deducing that this engagement will lead to a shift in the way reality is perceived, is not challenged. This should be kept in mind when assessing the potential of Cuban text-based artworks like the ones we have examined. Within the last years several artists from everywhere have developed an interest in collaborative, participative and socially-engaged art. Those projects have been based frequently on communication and role exchangeability, seeking to dismantle the traditional distribution of positions within the art world and to propel social transformation through artistic means. However, there is a distance between the intention and the potentiality conferred to visual translation, and the way it operates in each particular project. Being symbolic translation useful to penetrate the interstices of the Cuban public sphere and revealing how it works, only in a few cases this will be followed by an affirmative transformation in the role conferred to the audience.

Nevertheless, in some cases - La realidad absoluta can appear as the clearest among the analyzed examples - a possibility appears through the recuperation of speech and experience. From that viewpoint, those projects develop intersubjective experiences glossing over the politics of power that inhere within art worlds themselves. In that sense, in their most practical aspects - the way Gómez's installation opens up a space for interaction, the way Wellesley's variations on truth can work as class exercises - can be framed from a position related to Tonel's emancipative aspirations for artistic practice. This bears important implications concerning the configuration of new subjectivities in the form of art audiences: the reach and the limitations of language-based projects such as the ones I have examined are especially eloquent of the contradictions of participatory art in Cuba. In any case, I have tried to show how the limitations constraining the difficulties of translation within the Cuban context cannot be conceived without paying attention to how visual arts have become a privileged language within the Cuban sphere, an institution in itself loaded with strong political implications difficult to avoid. 


\section{REFERENCES}

BorRÀs, María Llüísa and ZAYA, Antonio (eds.) (1996), Cuba siglo XX: modernidad y sincretismo. Las Palmas, CAAM.

Bourriaud, Nicolas (2002), Relational Aesthetics. Paris, Les Presses du Réel.

CAMnitzer, Luis (2003), New Art of Cuba. Austin, University of Texas Press. DOI: <http://dx.doi.org/10.1016/S0261-3050(97)81422-2>

FABIAN, Johannes (1991), Language and Colonial Power: The Appropriation of Swahili in the Former Belgian Congo, 1880-1938. Berkeley, University of California Press.

Fraser, Andrea (2005), "From the Critique of Institutions to an Institution of Critique", in ArtForum, 44 (1), pp. 278-286.

Fusco, Coco (2001), The Bodies that Were not Ours: and Other Writings. New York, Routledge. DOI: <http://dx.doi.org/10.4324/9781315012735>

Groys, Boris (2003), "Back from the Future", in Third Text, 17 (4), pp. 323331. DOI: <http://dx.doi.org/10.1080/0952882032000166152>

KESTER, Grant (2011), The One and the Many. Contemporary Collaborative Art in a Global Context. Durham, Duke University Press. DOI: http://dx.doi.org/10.1215/9780822394037-001

LLANES, Llilian (2010), Más allá de la crítica: recopilación de textos sobre arte. Havana, ArteCubano.

Mosquera, Gerardo (2009), States of Exchange. Artists from Cuba. London, InIVA.

(2010), Caminar con el diablo. Textos sobre arte, internacionalismo y culturas. Madrid, Exit Books.

RANCIÈrE, Jacques (2004), The Politics of Aesthetics. The Distribution of the Sensible. London, Continuum. DOI: <http://dx.doi.org/10.1177/03058298060340030919> (2010), Dissensus. On Politics and Aesthetics. London, Continuum.

RAUNIG, Gerald and RAY, Gene (ed.) (2009), Art and Contemporary Critical Practice. Reinventing Institutional Critique. London, Mayfly.

SAntanA, Andrés Isaac (ed.) (2007), Nosotros, los más infieles. Narraciones críticas sobre el arte cubano (1993-2005). Murcia, CENDEAC.

"Tonel" (Antonio Eligio Fernández) (2006), "Arte cubano: la llave del Golfo y cómo usarla", in Magaly Espinosa and Kevin Power (eds.), El Nuevo arte cubano. Antología de textos críticos. Santa Monica, Perceval Press, pp. 41-51.

"Tonel" (Antonio Eligio Fernández) (1996), “70, 80, 90...tal vez 100 impresiones sobre el arte en Cuba", in María Lluïsa Borràs y Octavio Zaya (eds.), Cuba siglo XX: modernidad y sincretismo. Las Palmas, CAAM, pp. 281-303.

WeIsS, Rachel (2011), To and From Utopia in the New Cuban Art. Minneapolis, University of Minnesota Press. DOI: <http://dx.doi.org/10.1111/j.1935-4940.2012.01210.x> 